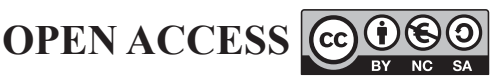

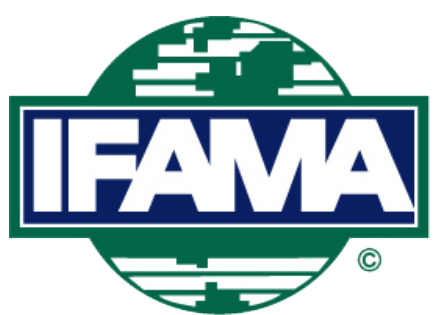

International Food and Agribusiness Management Review

Volume 24, Issue 6, 2021; DOI: 10.22434/IFAMR2020.0141

Received: 3 September 2020 / Accepted: 28 January 2021

Special Issue: IFAMA 2020 Symposium

\title{
What links neuroscience to agricultural economics? A review of neuroscientific methods literature in agricultural economic research and marketing
}

\section{REVIEW ARTICLE}

\author{
Sirkka Schukat $^{\oplus a}$, Marie Diekmann ${ }^{\mathrm{b}}$ and Heinke Heise ${ }^{\mathrm{b}}$ \\ ${ }^{a} M S c,{ }^{b}$ Postdoctoral Researcher, Department of Agricultural Economics and \\ Rural Development, Agribusiness Management, Georg-August-University \\ Göttingen, Platz der Göttinger Sieben 5, 37073 Göttingen, Germany
}

\begin{abstract}
Research into consumer behavior is confronted with a multitude of challenges and special features. These become apparent in economic decision-making situations in which actual behavior deviates massively from rational explanatory models, such as the model of homo economicus, or when discrepancies are observed between statements made by individuals and their actions. As a common intersection between the economic and the neurosciences, neuroeconomics investigates human decision-making behavior from a neuroscientific perspective. The focus is particularly on explaining these antagonisms of human behavior and deriving motives. With the help of this potentially expandable knowledge, it is possible to subtly influence individual purchasing decisions at the neural level and to predict consumer behavior at the market level. In agricultural economics, for example in the field of food marketing, neuroeconomics could contribute to more reflective purchasing decisions and thus counteract global health challenges such as obesity. To date, no research has been conducted into the extent to which neuroeconomics has already been applied in agricultural scientific research. The objectives of the article are to provide an aggregated basic knowledge in the field of neuroeconomics, taking into account the applied methods as well as a literary overview of previous research in the context of agricultural economics. The article addresses all those interested in getting an overview of what neuroeconomics entails and how it is already being applied in agricultural research without any prior neuroscience background.
\end{abstract}

Keywords: neuroeconomics, consumer neuroscience, neuromarketing, consumer research, agro-economic research JEL code: Q, M, Z

\footnotetext{
${ }^{(1)}$ Corresponding author: sirkka.schukat@uni-goettingen.de
} 


\section{Introduction}

Neuroeconomics is an interdisciplinary science at the interface of economic research, psychology and neuroscience (Weber, 2017). For about 15 years scientists from these different disciplines have been working to understand, describe and predict human decision-making more comprehensively using methods, theories and models of the involved knowledge domains. The field of neuroeconomics has developed from basic science to very application-orientated research despite the very short time it has existed. The results of this research were embedded in the discovery and developments of new areas of research today known as consumer neuroscience, decision neuroscience, neurofinance and neuromarketing (Reimann and Weber, 2011). The growing importance of neuroeconomics, especially in the fields of consumer neuroscience and neuromarketing, is reflected, for example, in the fact that large market research institutes such as Nielson and Ipsos, but also companies like Coca-Cola have established their own company internal department for neuroeconomics (Plassmann et al., 2015). While much of the social and humanistic models of human decision-making are based on the image of the disembodied agent and rational decision-maker, neuroeconomic research attempts to contrast it with a biologically-based and therefore biologically limited image of humanity (Weber, 2017). Therefore, its principal aim is to portray human behavior in economic decision-making situations on a neuronal level and to derive individual-related motives situationally (Knutson et al., 2007). The addition of neuroeconomics to the field of economics is relevant, because human behavior is largely based on biological processes. It is therefore not unlikely that a progressive understanding of biology underlying human behavior could provide a way to better understand and predict human behavior and thus, consumer behavior. Thus, current studies show not only how buying decisions proceed in the brain, but also how they differ individually and even predictions about aggregated market behavior (Plassmann and Weber, 2015). Thereby, the application of neuroscientific methods allows insights into neuronal activities and offers an approach to uncover previously unknown mechanisms during economic decision-making (Plassmann et al., 2015).

When buying agricultural products, it is apparent that there is often a discrepancy between consumers' expressed attitude and willingness to buy, as opposed to the actual purchase. This is to be demonstrated using the example of the majority willingness to buy animal welfare products, as it is highly topical and on the other hand there is no complete explanation for this discrepancy. According to a consumer analysis by Weinrich et al. (2014), the interviewees showed a clear preference for milk from cows kept outdoors and indicated a willingness to buy milk from cows kept outdoors, while at the same time deviating from this behavior when actually buying. Similar results were also obtained from empirical studies, which show that consumers from Germany are $45 \%$ definitely willing and $44 \%$ tend to be willing to pay higher prices for animal based products from animal-friendly husbandry (Federal Ministry of Food and Agriculture, 2016). The announced majority willingness for animal welfare initiatives also emerges from further studies (Enneking et al., 2019; Schulze et al., 2008). This phenomenon between intended and real purchasing behavior is known as the 'attitude-behavior gap' (Vanhonacker et al., 2010). Previous models seem mostly unsuitable to explain consumer behavior in this context. However, studies from neuroeconomics could provide valuable information to explain the behavior and, in a next step, to predict and guide it. By now, there are hardly any studies on how neuroeconomics is considered in agricultural research and whether it offers new possibilities in understanding consumer decision behavior. Therefore, the guiding research question of this article is: in which research fields have agro-economic issues been considered in neuro-economic research? This paper complements previous research with an explorative study aimed at mapping different neuroscientific methods in agri-food economic and marketing research. This aim will be put into practice by comparing neuroscientific methods and presenting a research overview in the context of agricultural economics. Examples for each of the fields identified are provided.

\section{Comparison of applied neuroscientific methods}

In neuroeconomic research, a variety of methods are applied, which are mainly taken from cognitive neuroscience. The most commonly used methods as well as their mode of action are presented below. First of all, some general differences within the individual methods have to be differentiated. A distinction is 
made between invasive and non-invasive methods. Non-invasive methods allow the measuring device to be attached to the body, whereas invasive systems require chemicals or devices to be applied to the body (Ruff and Huettel, 2014). Other relevant distinguishing features are the spatial and temporal resolution of a system. Spatial resolution refers to the accuracy which local physiological changes in brain regions can be measured. The temporal resolution refers to the accuracy with which it is possible to measure when a cognitive event occurs (Huettel et al., 2009). Furthermore, the methods can be subdivided in terms of mobility, field of application and application object, but also in relation to costs. These seven distinguishing characteristics are used for the following method comparison. Methods used include single-unit recording, electro-dermal activity, eye tracking, electroencephalography, magnet-encephalography, functional magnetic resonance imaging (fMRI), positron emission tomography and functional near-infrared spectroscopy (fNIRS). As applied research is mostly done with eye tracking, fMRI and fNIRS, the following explanations focus on these three methods.

Eye tracking is used for the direct recording of human eye movements as a basis of investigation for the understanding of information search processes and the steering of attention (Weber, 2017). In the context of eye movement measurement, visual attention behavior is thus examined to determine which objects are focused on by persons and for which period of time (Duchowski, 2007). The most commonly used procedure is based on the principle of the cornea reflex, which detects the position of the eye as it performs movements. In this context, eye-tracking functions as a superordinate term for various stationary or mobile procedures within its own discipline and at the same time represents a non-invasive method. Among the various fields of application of eye tracking are primarily cognitive psychology, human-computer interaction and marketing. Especially in marketing, eye tracking has taken an important position as it helps to observe the actual actions of consumers. Regarding its use, there are various advantages and disadvantages. For example, eye trackers enable the exploration of decisions by means of new analysis methods in which determined attention measures are couples with innovative decision models (Krajbich et al., 2012). Especially stationary devices are able to provide examination results with a high temporal resolution (Weber, 2017). Due to the average acquisition costs of 20,000 Euros and the running costs of about 25 Euros per hour, eye tracking can be considered very inexpensive (Rampl et al., 2011). Disadvantages of its use arise especially in the context of systems that can be used in mobile applications, as they have a low temporal resolution and at the same time a high data-evaluation effort. This results from programming, installation and insufficient user-friendliness (Weber, 2017).

The fMRI is still strongly established in the neuroeconomic research field. Furthermore, it is also used in medicine and physics. It uses regular, stationary MRI equipment and enables a non-invasive process to record human biological brain activity at the neural level in real time (Houser and McKabe, 2014). Thus, even a simulation of economic decision situations can be performed. In the course of the respective experiment, the person goes into an fMRI scanner for a period of 60 to 90 minutes. The fMRI is in fact a functional imaging procedure. It uses strong magnetic field to generate images of biological tissue (Huettel et al., 2009). At the beginning of the process, a simple structural image of the brain is generated. A stimulus, which may be visual, acoustic, gustatory, olfactory or haptic, is then applied to the person and his or her reaction is recorded (Schilke and Reimann, 2007). At the same time, structural images of the brain, based on neuronal activity, are recorded again within short intervals. Finally, the results of the data evaluation are aggregated and the activated brain regions are color-coded. Thus, the fMRI is based on the assumption that neuronal activity produces local physiological changes in the brain. Active neurons need glucose and oxygen for their work (Bear et al., 2016). The demand for oxygen and energy that the active neurons need to perform work is met by the brain from the local blood supply, whereby the blood supply increases with the metabolic activity of the neurons (Attwell and Iadecola, 2002). This means that the signal to be detected by fMRI is sensitive to the amount of deoxyhaemoglobin in the blood (Ward, 2015). Overall, fMRI allows non-invasive and thus harmless measurements with high spatial resolution without the injection of contrast agents. In addition, according to Houser and McCabe (2014) it is an easy to implement procedure. The main disadvantage is that the measured blood flow change represents rather a slow process, so that the temporal resolution only has a span of one to four seconds (Weber, 2017). Furthermore, decoupling of the neuronal to the vascular vessel 
signal can lead to the problem of misinterpretation, for example due to medication. Another disadvantage is that fMRI cannot be used outside the laboratory. In this context, it is also important to point out the loud noise generated by the scanner itself and the obligatory fixation of the test person (Schilke and Reimann, 2007). Finally, the cost-intensive use of the technology should be pointed out. In addition to acquisition costs of two to three million euros, the operating costs amount to 200 up to 500 Euros per hour (Rampl et al., 2011).

The third method to be introduced it fNIRS as a method for functional imaging, which is increasingly used in cognitive neuroscience. With this method it is possible to measure both the blood flow of the cerebrum and the change in blood flow in a specific brain region during neuronal activity (Kirilina et al., 2012). For this purpose, human tissue is illuminated by near-infrared light with a wavelength spectrum of 650 to 950 nanometers, which enables non-invasive application. The light sources used are laser-emitting diodes placed directly on the scalp (Okada and Delpy, 2003). Changes in oxy- and deoxyhaemoglobin act as parameters for neuronal activity (Lloyd-Fox et al., 2010). In scientific practice, both stationary and mobile systems are used. A major advantage of fNIRS is its compatibility with a variety of other neuroscientific methods, such as fMRI or eye tracking. At the same time fNIRS offers a high temporal resolution. Another important advantage is that mobile fNIRS can be used outside the laboratory in field studies and, thanks to its quiet operation, is also suitable for the investigation of auditory stimuli (Kopton and Kenning, 2014). Acquisition costs range widely from 10,000 to 200,000 Euros. A disadvantage of fNIRS is its high sensitivity to body movements and fluctuations in blood flow in the scalp, which can distort activity records (Kirilina et al., 2012). In addition, the spatial resolution of fNIRS is low and the investigation of deeper brain structures at a depth of 20 to 30 millimeters is very limited (Kopton and Kenning, 2014). An overview which compares the differences in term of method-specific advantages or disadvantages with the corresponding properties of imaging, method, spatial and temporal resolution, mobility, object and field of application as well as the costs, is given in Table 1.

\section{Methods}

Methodically, a literature review was applied. The literature was considered from 2003 onwards. The related study by Araujo et al. (2003) is considered one of the first in the field of neuroeconomics to feature neuroimaging techniques. The literature search was limited to studies that were either directly related to agriculture itself or to agricultural and food marketing. In addition, studies were considered that look at processed products and can thus be placed in the context of agricultural and food marketing. Product design was also included, since in the case of processed products it is inseparably linked to the marketing of food. The main objective of this work is to identify those areas of agro-economic research in which neuroscientific methods have already been applied and to summarize them by means of a literature review. A structured, twostage procedure was chosen for the search. In a first step, national and international journals which publish

Table 1. Most common neuroscientific methods applied in neuroeconomics. ${ }^{1}$

\begin{tabular}{llll}
\hline & Eye tracking & fMRI & fNIRS \\
\hline $\begin{array}{l}\text { Method } \\
\text { Spatial resolution }\end{array}$ & Non-invasive & Non-invasive & Non-invasive \\
Temporal resolution & N/A & Very high & Low \\
& $\begin{array}{l}\text { Very high (mobile) or low } \\
\text { (stationary) }\end{array}$ & Low & Low \\
Mobility & Stationary or mobile & Stationary & \\
Subject & Animals, humans & Humans & Stationary or mobile \\
Application & Cognitive psychology, & Medicine, neuroscience, & Animals, humans \\
& human-computer- & physics, dominating in & neuroscientific research \\
& interaction and marketing & neuroeconomics & \\
Costs & Low & High & Medium \\
\hline
\end{tabular}

${ }^{1}$ fMRI = functional magnetic resonance imaging; fNIRS = functional near-infrared spectroscopy; N/A = not applicable. 
papers in German or English language from the scientific fields of psychology, economics, neuroscience and agricultural economics were searched for various keywords. These keywords referred to the method used (e.g. fMRI, eye tracking, fNIRS), the research area (e.g. neuroeconomics, consumer behavior, agricultural economics, neuromarketing, agriculture) and products or product properties (e.g. organically produced, animal welfare, food labeling). The search strings consisted of combinations of these keywords. Subsequently, the search was extended to web-based platforms, especially Scopus, PubMed, Google scholar and the electronic journals library of the Lower Saxony State and University Library of Göttingen. In a second step, the articles classified as relevant were analyzed and further literature was extracted. The selection of articles was chosen in such a way as to provide the most comprehensive impression possible of what neuroeconomics covers in its research. Thus, the number of studies that are too similar in content was reduced. The aim here is to present examples of areas in which neuroeconomics has already been applied in agro-economic research, rather than to generate a complete overview covering all neuro-economic studies. After selection, the literature references have been systematized and categorized into three topics: brands and preferences, nutritional as well as purchasing behavior and advertising and marketing. Depending on content and keywords, a selected study was classified within a category.

\section{Results}

The research overview will be illustrated by three different topics. Overall, the three categories brands and preferences, nutritional as well as purchasing behavior and advertising and marketing dominate, although these cannot always be completely separated from each other in terms of content. The first category brands and preferences include studies aiming to detect, but also to predict consumers' preferences in food choices. These efforts were examined at the neural level, taking into account varying factors and products. Therefore, the influence of different factors in the formation of preferences in the corresponding context will be investigated. For example, with the help of neuroeconomics, the willingness of consumers to pay specific costs for their preferred beverages was investigated. These include fMRI experiments in which, for example consumer decisions had to be made between soft drinks of different brands or between juices with different flavoring (McClure et al., 2004; O'Doherty et al., 2006). In addition, there were efforts to determine and predict preferences for Coca-Cola, milk, isotonic drinks, juices, mineral water and beer based on neuronal activity using fNIRS (Luu and Chau, 2009). Investigations on preference formation in wines include other variable factors, such as specific price information of beverages or taste perception (Plassmann et al., 2008). In addition to beverages, other foods are also coming to the fore in the research of preferences. For example, rice, chocolate and coffee were examined with regard to their preferences, while these only differed on the basis of whether or not a fair-trade label was present (Enax et al., 2015b). Participants reported a perceived better and more intense taste for chocolate associated with a fair-trade label. Crespi et al. (2015) conducted a similar experiment with milk labelling Ellis et al. (2019) examined the willingness to pay for food produced with recycled water and crickets as a substitute for water-intensive proteins such as beef and demonstrate that even sustainability issues can become subject of neuroeconomic research. By applying neuroscientific imaging methods, especially fMRI technology, consistent neuronal activation of the brain could be shown in all of the mentioned investigations, which are associated with the formation of preferences. These include activities of the ventromedial prefrontal cortex, the ventral striatum, the orbitofrontal cortex and the dorsolateral prefrontal cortex. By means of eye tracking, preferences in the selection of biscuits could be examined in more detail, which showed differences in shape, taste, content composition and topping (Khushaba et al., 2013). Here it was shown that the topping and flavors of the biscuits have a greater influence on the willingness to pay and purchase decisions than the shape of the biscuits. An overview of the first category is given in Table 2.

The second category nutritional and purchasing behavior is about developing an understanding of the motives for consumption and responses at the point of sale. Particular research effort has been made here in the subjective perception of food labels. At one study, the buying behavior of convenience products could be observed and recorded directly at the point of sale. Cognitive controlled, impulsive and habituated purchases of the products were taken into account (Groeppel-Klein et al., 2005). Kühn et al. (2016) tested 
Table 2. Overview of neuroscientific based research in brands and preferences. ${ }^{1}$

\begin{tabular}{|c|c|c|c|}
\hline Authors and year & Research topic & Methods & Results \\
\hline $\begin{array}{l}\text { McClure et al. } \\
\text { (2004) }\end{array}$ & $\begin{array}{l}\text { Investigation of brand } \\
\text { influence on preference } \\
\text { formation at Coca-Cola and } \\
\text { Pepsi }\end{array}$ & fMRI & $\begin{array}{l}\text { The activity of the ventromedial prefrontal } \\
\text { cortex can be used to predict a preference. } \\
\text { The activity of the dorsolateral prefrontal } \\
\text { cortex plays a role in cognitive bias }\end{array}$ \\
\hline $\begin{array}{l}\text { O’Doherty et al. } \\
\text { (2006) }\end{array}$ & $\begin{array}{l}\text { Identification of indicators } \\
\text { for the predictability of food } \\
\text { preferences }\end{array}$ & fMRI & $\begin{array}{l}\text { Those with activities in the midbrain and part of } \\
\text { the ventral striatum are related to actual food } \\
\text { preferences }\end{array}$ \\
\hline $\begin{array}{l}\text { Plassmann et al. } \\
\text { (2008) }\end{array}$ & $\begin{array}{l}\text { Research into the effects of } \\
\text { price increases in wines on } \\
\text { neuronal activity }\end{array}$ & fMRI & $\begin{array}{l}\text { The price increase influences the subjective } \\
\text { taste perception regarding the physiological } \\
\text { properties of the wine and leads to an } \\
\text { increased activity in the orbitofrontal cortex }\end{array}$ \\
\hline $\begin{array}{l}\text { Luu and Chau } \\
\text { (2009) }\end{array}$ & $\begin{array}{l}\text { Investigation of the preference } \\
\text { for beverages }\end{array}$ & fNIRS & $\begin{array}{l}\text { The subjective preference between two drinks } \\
\text { correlates with neuronal activity in the } \\
\text { prefrontal cortex }\end{array}$ \\
\hline $\begin{array}{l}\text { Khushaba et al. } \\
\text { (2013) }\end{array}$ & $\begin{array}{l}\text { The influence of biscuit } \\
\text { product design on } \\
\text { preferences }\end{array}$ & Eye tracking & $\begin{array}{l}\text { The areas of the frontal and occipital lobes are } \\
\text { involved in preference formation }\end{array}$ \\
\hline $\begin{array}{l}\text { Enax et al. } \\
(2015 b)\end{array}$ & $\begin{array}{l}\text { Influence of Fair Trade } \\
\text { labels on the evaluation and } \\
\text { selection of food }\end{array}$ & fMRI & $\begin{array}{l}\text { The fair-trade labels increase the activity in } \\
\text { ventral striatum and ventromedial prefrontal } \\
\text { cortex } \\
\text { The fair-trade labels influence the subjective } \\
\text { sense of taste and the individual willingness } \\
\text { to pay }\end{array}$ \\
\hline $\begin{array}{l}\text { Crespi et al. } \\
\text { (2015) }\end{array}$ & $\begin{array}{l}\text { Investigation of the influence } \\
\text { of labelling on the choice of } \\
\text { milk. }\end{array}$ & fMRI & $\begin{array}{l}\text { The final decision appears to be most strongly } \\
\text { correlated with areas in the medial prefrontal } \\
\text { cortex. }\end{array}$ \\
\hline Ellis et al. (2019) & $\begin{array}{l}\text { Determination of the } \\
\text { willingness to pay for food } \\
\text { produced with recycled water } \\
\text { and crickets as a substitute } \\
\text { for water-intensive proteins } \\
\text { such as beef. }\end{array}$ & fMRI & $\begin{array}{l}\text { Activation in the insular cortex is assumed } \\
\text { when images of foods made with recycled } \\
\text { water or crickets are shown, indicating that } \\
\text { these foods are associated with feelings of } \\
\text { disgust. }\end{array}$ \\
\hline
\end{tabular}

the prediction of purchasing behavior of shoppers of chocolate bars at the point of sale, while Krampe et al. (2018) examined the neuronal effect of the supermarket environment on the consume more closely. The latest scientific findings include the observation of consumer behavior when buying meat products at the supermarket (Gier et al., 2018). It is shown that visual stimuli at the point of sale can influence buying behavior. Other studies investigated specific food labeling systems, in particular the traffic light food labeling system for the nutritional content of food. The subject of the research was thus less the product itself, but rather the way in which information related to the product is perceived and processed by the consumer on a subjective level. For this purpose, the test subjects were presented with different labeling systems which were subjected to an individual assessment (Enax et al., 2015a; Graham and Jeffery, 2012; Jones and Richardson, 2007). In particular, using eye tracking systems, empirical evidence has been found that the design of nutritional information in foods is an effective way to attract consumers' attention (Ballco et al., 2019; Graham and Jeffery, 2012; Jones and Richardson, 2007; Velaquez and Pasch, 2014). Traffic light signals in combination with nutritional labelling on foods can raise consumer awareness of health issues. 
Also, the position of food labels and the arrangement of information on the label have a significant influence on the consumer's attention. Furthermore, the fair-trade labels influence the subjective sense of taste and the individual willingness to pay. However, consistent results were also obtained by means of fMRI (Enax et al., 2015a). In addition, Busch et al. (2015) provide results that address consumer attention using the example of pig fattening in an eye tracking experiment. It was shown that consumers are more likely to refuse to keep animals without straw. A recent study investigates fish farming via aquaponics and shows that the test persons prefer natural production methods (Schröter and Mergenthaler, 2019).

The investigation of nutritional behavior mainly includes the role of food as a reward. The background is the determination of correlations between taste stimuli, neuronal activations in certain regions of the brain and the tendency to be overweight. In the associated experiments, the subjects were fed various, mainly high-calorie, foods and their neuronal activity was measured. These included, for example, the illustration of chocolate cake and ice cream (Beaver et al., 2006). In a basically similar experimental set-up, in addition to the highcalorie foods cheesecake and nachos, the low-calorie foods vegetables and fish were also used (Stoeckel et al., 2008). This experiment was also conducted with sweets such as chocolate bars on the one hand, but also fruit and vegetables on the other hand (Hare et al., 2011). A further modification of the experiment includes the perception and evaluation of chocolate milk shakes with high fat content as well as milk shakes with low fat content (Ng et al., 2011). The previous remarks were consistent in that the neuronal activities that could be determined in the orbitofrontal cortex, amygdala, the ventral striatum and the insula correlate with the sensitivity to food as a reward and the tendency to be overweight (Beaver et al., 2006; Del Parigi et al., 2005; Hare et al., 2011; Ng et al., 2011; Stoeckel et al., 2008). The authors claim that the improvement of individual eating habits can be initiated through targeted attention guidance. Furthermore, a study could be identified which takes into account the personal convictions of food choices. For this purpose, subjects were asked to state their willingness to pay for milk, eggs and bread, which either carried an organic label or did not carry an organic label, whereby increased activities in the ventral striatum and the dorsolateral prefrontal cortex can also be recorded as a result (Linder et al., 2010). Two studies focused on the efforts of dietary behavior. On the one hand, the long-term effect of caffeine and on the other hand of omega-3 fatty acids on the brain, especially the blood flow in the prefrontal cortex, and cognitive performance is demonstrated (Jackson et al., 2012; Kennedy and Haskell, 2011). An overview of the second category is given in Table 3.

In the category advertising and marketing, the effects of marketing measures in the field of agricultural marketing are examined in more detail. The focus is on visual simulation, for example in the form of product design, and the resulting neural activations and actual actions. The individual willingness to pay for food was determined by showing test participants pictures, for example of chocolate, with associated prices to decide for or against the purchase (Knutson et al., 2007). In a further study, the same test set-up was extended with regard to the objects of evaluation to include the food selection chips and other sweets (Plassmann et al., 2007). Francisco et al. (2015) investigated the willingness to pay for eggs from different types of farming. All three studies independently found neuronal activations in the ventral striatum, insula, dorsolateral prefrontal cortex and orbitofrontal cortex during the release of willingness to pay (Francisco et al., 2015; Knutson et al., 2007; Plassmann et al., 2007). In a study on the evaluation of product designs, various fast moving consumer goods packaging, e.g. of pizza, were evaluated with regard to their attractiveness and it could be shown that attractive packaging causes increased activity in the occipital lobe (Stoll et al., 2008). Hubert et al. (2011) came to the same conclusions in their study on the attractiveness of packaging. Liao et al. (2015) found that chocolate packaging was evaluated with regard to its attractiveness and showed that pictures on packaging tend to trigger emotions unconsciously, while colors and fonts tend to be perceived consciously. Finally, in an experiment with wine, marketing placebo effects could be demonstrated by offering an identical wine at two different prices and the subjective taste perception of the test persons preferred the higher-priced variant, which was associated with increased activity in the ventral striatum and the ventromedial prefrontal cortex (Plassmann and Weber, 2015). It can thus be implied that the ventromedial cortex plays an important role in the evaluation of various consumer decisions, such as food intake, drinking or shopping, but also when consumer act out of conviction (Karmarkar and Yoon, 2016). Furthermore, Kenning (2014) assumes that a large part of the buying behavior can be explained by the activation of the striatum, insula and prefrontal cortex. 
Table 3. Overview of neuroscientific based research in nutritional and purchasing behavior. ${ }^{1}$

\begin{tabular}{|c|c|c|c|}
\hline $\begin{array}{l}\text { Authors and } \\
\text { year }\end{array}$ & Research topic & Methods & Results \\
\hline $\begin{array}{l}\text { Araujo et al. } \\
\text { (2003) }\end{array}$ & $\begin{array}{l}\text { Investigation of the taste- } \\
\text { olfactory convergence in the } \\
\text { human brain }\end{array}$ & fMRI & $\begin{array}{l}\text { A small part of the anterior insula responds to taste and olfactory stimuli. } \\
\text { Activations to combined olfactory and taste stimuli were found where there was no or little } \\
\text { activation for either of the two stimuli in a part of the orbitofrontal cortex. }\end{array}$ \\
\hline $\begin{array}{l}\text { Groeppel- } \\
\text { Klein et al. } \\
(2005)\end{array}$ & $\begin{array}{l}\text { Investigation of dermal } \\
\text { reactions to purchase decisions } \\
\text { on convenience products }\end{array}$ & $\begin{array}{l}\text { Electro- } \\
\text { dermal } \\
\text { activity }\end{array}$ & $\begin{array}{l}\text { Cognitively controlled and impulsive shoppers show a higher dermal arousal response than } \\
\text { habitual shoppers. }\end{array}$ \\
\hline $\begin{array}{l}\text { Del Parigi et } \\
\text { al. (2005) }\end{array}$ & $\begin{array}{l}\text { Investigation of the reward } \\
\text { expectation in the form of food }\end{array}$ & fMRI & $\begin{array}{l}\text { The administration of liquid food after a defined fasting period causes a change in the blood } \\
\text { flow in the areas of the ventral striatum, the insula and the orbitofrontal cortex. }\end{array}$ \\
\hline $\begin{array}{l}\text { Beaver et al. } \\
(2006)\end{array}$ & $\begin{array}{l}\text { Exploring the role of food as } \\
\text { a reward }\end{array}$ & fMRI & $\begin{array}{l}\text { Sensitivity to food as a reward varies from individual to individual. } \\
\text { Sensitivity is associated with activation of the ventral striatum, amygdala, midbrain and } \\
\text { orbitofrontal cortex. }\end{array}$ \\
\hline $\begin{array}{l}\text { Jones and } \\
\text { Richardson } \\
(2007)\end{array}$ & $\begin{array}{l}\text { Influence of traffic light signals } \\
\text { on food on attention }\end{array}$ & $\begin{array}{l}\text { Eye } \\
\text { tracking }\end{array}$ & $\begin{array}{l}\text { Traffic light signals in combination with nutritional labelling on foods can raise consumer } \\
\text { awareness of health issues. }\end{array}$ \\
\hline $\begin{array}{l}\text { Stoeckel et al. } \\
(2008)\end{array}$ & Research on food as a reward & fMRI & $\begin{array}{l}\text { The high-calorie foods show a stronger activation of the reward system, ergo the orbitofrontal } \\
\text { cortex, amygdala, ventral striatum, ventromedial prefrontal cortex and insula in overweight } \\
\text { people than in normal weight people. }\end{array}$ \\
\hline $\begin{array}{l}\text { Linder et al. } \\
(2010)\end{array}$ & $\begin{array}{l}\text { Influence of labeling on the } \\
\text { subjective assessment of food }\end{array}$ & fMRI & $\begin{array}{l}\text { The increased activity in ventral striatum is demonstrated in daily organic consumers, } \\
\text { especially in Nucleus accumbens and dorsolateral prefrontal cortex, for foods with organic } \\
\text { labelling. }\end{array}$ \\
\hline $\begin{array}{l}\text { Hare et al. } \\
(2011)\end{array}$ & $\begin{array}{l}\text { Influence of attention-direction } \\
\text { on health messages on eating } \\
\text { behavior }\end{array}$ & fMRI & $\begin{array}{l}\text { Focusing attention on the health claims of food increases neuronal activity in the ventromedial } \\
\text { prefrontal cortex and dorsolateral prefrontal cortex. } \\
\text { The improvement of individual eating habits can be initiated through targeted attention } \\
\text { guidance. }\end{array}$ \\
\hline $\begin{array}{l}\text { Ng et al. } \\
(2011)\end{array}$ & $\begin{array}{l}\text { Investigation of neuronal } \\
\text { activity for taste stimuli in } \\
\text { overweight persons }\end{array}$ & fMRI & $\begin{array}{l}\text { The neuronal activation of amygdala and ventromedial prefrontal cortex is stronger after } \\
\text { gustatory stimulation in overweight persons than in normal weight. }\end{array}$ \\
\hline $\begin{array}{l}\text { Kennedy } \\
\text { and Haskell } \\
(2011)\end{array}$ & $\begin{array}{l}\text { influence of caffeine on the } \\
\text { concentration }\end{array}$ & fNIRS & The modulation of blood flow in the prefrontal cortex can be achieved by caffeine. \\
\hline $\begin{array}{l}\text { Jackson et al. } \\
(2012)\end{array}$ & $\begin{array}{l}\text { Influence of omega-3 fatty } \\
\text { acids on the performance of } \\
\text { cognitive tasks }\end{array}$ & fNIRS & The supply of omega-3 fatty acids leads to increased blood flow in the prefrontal cortex. \\
\hline $\begin{array}{l}\text { Graham } \\
\text { and Jeffery } \\
(2012)\end{array}$ & $\begin{array}{l}\text { Influence of different } \\
\text { nutritional claims on food } \\
\text { labels }\end{array}$ & $\begin{array}{l}\text { Eye } \\
\text { tracking }\end{array}$ & $\begin{array}{l}\text { The position of food labels and the arrangement of information on the label have a significant } \\
\text { influence on attention. }\end{array}$ \\
\hline $\begin{array}{l}\text { Velazquez and } \\
\text { Pasch (2014) }\end{array}$ & $\begin{array}{l}\text { Influence of labeling on the } \\
\text { subjective assessment of food }\end{array}$ & $\begin{array}{l}\text { Eye } \\
\text { tracking }\end{array}$ & $\begin{array}{l}\text { The position of food information and their arrangement on products have influence on } \\
\text { consumer's attention }\end{array}$ \\
\hline $\begin{array}{l}\text { Enax et al. } \\
(2015 \mathrm{a})\end{array}$ & $\begin{array}{l}\text { Influence of fair trade labels on } \\
\text { the evaluation and selection } \\
\text { of food }\end{array}$ & fMRI & $\begin{array}{l}\text { The fair-trade labels increase the activity in ventral striatum and ventromedial prefrontal cortex. } \\
\text { The fair-trade labels influence the subjective sense of taste and the individual willingness to } \\
\text { pay. }\end{array}$ \\
\hline $\begin{array}{l}\text { Busch et al. } \\
(2015)\end{array}$ & $\begin{array}{l}\text { Study of the visual processing } \\
\text { of images from pig fattening }\end{array}$ & $\begin{array}{l}\text { Eye } \\
\text { tracking }\end{array}$ & $\begin{array}{l}\text { Attention is primarily focused on the body. } \\
\text { The activity opportunities of the pigs are not identified. } \\
\text { The pigs' postures influence the attention. }\end{array}$ \\
\hline $\begin{array}{l}\text { Kühn et al. } \\
\text { (2016) }\end{array}$ & $\begin{array}{l}\text { Prediction of buying behavior } \\
\text { using fMRI data }\end{array}$ & fMRI & $\begin{array}{l}\text { The activities in medial orbitofrontal cortex and the nucleus accumbens correlate with the } \\
\text { actual buying behavior. }\end{array}$ \\
\hline $\begin{array}{l}\text { Krampe et al. } \\
(2018)\end{array}$ & $\begin{array}{l}\text { Analysis of the effectiveness } \\
\text { of marketing strategies at the } \\
\text { point of sale }\end{array}$ & fNIRS & $\begin{array}{l}\text { The activity of orbitofrontal cortex and dorsolateral prefrontal cortex is directly related to the } \\
\text { purchase decision. }\end{array}$ \\
\hline $\begin{array}{l}\text { Gier et al. } \\
(2018)\end{array}$ & $\begin{array}{l}\text { Investigation of visual stimuli } \\
\text { on buying behavior }\end{array}$ & $\begin{array}{l}\text { fNIRS } \\
\text { and eye } \\
\text { tracking }\end{array}$ & $\begin{array}{l}\text { Visual stimuli at the point of sale can increase the activity in orbitofrontal cortex and } \\
\text { dorsolateral prefrontal cortex and influence buying behavior. }\end{array}$ \\
\hline $\begin{array}{l}\text { Schröter and } \\
\text { Mergenthaler } \\
(2019)\end{array}$ & $\begin{array}{l}\text { Exploration of visual } \\
\text { perception of information } \\
\text { about aquaponics }\end{array}$ & $\begin{array}{l}\text { Eye } \\
\text { tracking }\end{array}$ & Production system with a more natural appearance is preferred by the test persons. \\
\hline $\begin{array}{l}\text { Ballco et al. } \\
\text { (2019) }\end{array}$ & $\begin{array}{l}\text { Nutritional claims on fast } \\
\text { moving consumer goods }\end{array}$ & $\begin{array}{l}\text { Eye } \\
\text { tracking }\end{array}$ & The presence of nutritional claims on fronts of packages increases the attention of consumers \\
\hline
\end{tabular}

${ }^{1} \mathrm{fMRI}=$ functional magnetic resonance imaging; fNIRS = functional near-infrared spectroscopy. 
Concrete and generally valid conclusions cannot be drawn from the studies presented. An explanation why no general conclusions can be drawn can be found in the answer to the following discussion. An overview of the third category is given in Table 4 .

\section{Discussion}

The guiding research question of this article was which different agro-economic categories were considered in neuroeconomic research. A definite limitation of the study is the fact that the manuscript is of explorative nature and comprises studies published since 2003 in German or English language. Thus, older papers from before 2003 and studies published in other languages are not part of our literature review. Therefore, the present contribution could not represent all studies related to agricultural economics. This results on the one hand from space restrictions, on the other hand because of repetitive content. The selected studies show that neuroscientific methods are also used in agricultural economics to study consumer behavior. It is clear that a large proportion of the selected studies originate from the field of food marketing. The main focus is on the willingness of consumers to pay in economic decision-making situations, but also on how attention can be drawn to products or product characteristics and how sustainable food and farm animal husbandry systems

Table 4. Overview of neuroscientific based research in advertising and marketing. ${ }^{1}$

\begin{tabular}{|c|c|c|c|}
\hline Authors and year & Research topic & Methods & Results \\
\hline $\begin{array}{l}\text { Knutson et al. } \\
\text { (2007) }\end{array}$ & $\begin{array}{l}\text { Identification of the brain } \\
\text { regions involved in purchase } \\
\text { decisions }\end{array}$ & fMRI & $\begin{array}{l}\text { The activation of the Nucleus Accumbens in } \\
\text { the ventral striatum correlates positively with } \\
\text { the purchase decision } \\
\text { Activation of the insula correlates negatively } \\
\text { with the decision to buy }\end{array}$ \\
\hline $\begin{array}{l}\text { Plassmann et al. } \\
\text { (2007) }\end{array}$ & $\begin{array}{l}\text { Examination of the } \\
\text { willingness to pay for food } \\
\text { purchases }\end{array}$ & fMRI & $\begin{array}{l}\text { The increased activities in orbitofrontal } \\
\text { cortex and dorsolateral prefrontal cortex } \\
\text { determine the willingness to pay for a } \\
\text { specific product }\end{array}$ \\
\hline Stoll et al. (2008) & $\begin{array}{l}\text { Study of the perception of } \\
\text { fast moving consumer goods } \\
\text { packaging }\end{array}$ & fMRI & $\begin{array}{l}\text { The attractively valued packages activate } \\
\text { regions in the occipital lobe } \\
\text { The unattractive packaging activates areas of } \\
\text { the frontal lobe and insula }\end{array}$ \\
\hline Hubert et al. (2011) & $\begin{array}{l}\text { Influence of brand } \\
\text { information on the } \\
\text { attractiveness rating of } \\
\text { product packaging }\end{array}$ & fMRI & $\begin{array}{l}\text { The development of cognitive distortions } \\
\text { correlates with neuronal activities in } \\
\text { dorsolateral prefrontal cortex and cingulate } \\
\text { cortex }\end{array}$ \\
\hline $\begin{array}{l}\text { Francisco et al. } \\
\text { (2015) }\end{array}$ & $\begin{array}{l}\text { Investigation of the } \\
\text { willingness to pay for the } \\
\text { choice of food }\end{array}$ & fMRI & $\begin{array}{l}\text { The increased activity in orbitofrontal cortex } \\
\text { and dorsolateral prefrontal cortex plays a } \\
\text { role in determining individual willingness to } \\
\text { pay }\end{array}$ \\
\hline Liao et al. (2015) & $\begin{array}{l}\text { Influence of the product } \\
\text { packaging of chocolate on } \\
\text { the emotional reaction }\end{array}$ & $\begin{array}{l}\text { Electrodermal } \\
\text { activity }\end{array}$ & $\begin{array}{l}\text { The subconscious and conscious emotions } \\
\text { are increasingly triggered by images } \\
\text { The conscious reactions are caused by colors } \\
\text { and fonts }\end{array}$ \\
\hline $\begin{array}{l}\text { Plassmann and } \\
\text { Weber (2015) }\end{array}$ & $\begin{array}{l}\text { Research on placebo effects } \\
\text { of food marketing }\end{array}$ & fMRI & $\begin{array}{l}\text { The susceptibility of the subjects to placebo } \\
\text { effects in marketing correlates positively } \\
\text { with the activity in the ventral striatum } \\
\text { and the ventromedial prefrontal cortex and } \\
\text { negatively with the activity of the insula }\end{array}$ \\
\hline
\end{tabular}

${ }^{1} \mathrm{fMRI}=$ functional magnetic resonance imaging; fNIRS = functional near-infrared spectroscopy. 
are perceived. In general, neuroeconomics offers the potential to enrich the classical methods of economics, although it will not replace them (Bernheim, 2009). As a relatively new research discipline, it has to deal with various challenges, which will be discussed below. In the first place, the possibility of observing and measuring neuronal activities and resulting decisions in real time should be emphasized (Plassmann et al., 2012). So far, neuroeconomics has been used to help segment the market. This is particularly important in case of preference research, where older methods tend to be oriented towards demographic variables, whereas today personal attitudes are more in the foreground (Venkatraman et al., 2012). Furthermore, research expenditures to date show that neuroeconomics has also been applied in the field of agricultural marketing. Often different food or beverages were administered in fMRI scanners in order to find correlations between taste perception and brain activation by means of imaging technology. One of the problems and limitations of neuroeconomics, with an average of 15 to 20 test persons, is clearly the lack of representativeness of the samples (Yarkoni, 2009). The highest samples of the studies examined are found in the field of eye-tracking, the lowest in the field of fMRI. A possible reason could be the costs associated with the fMRI experiments (Hubert and Kenning, 2008). Therefore, it should be mentioned in advance that the studies disclosed so far do not attain general validity and an interpretation of conclusions is only permissible within the context of the individual experiment (Weber, 2016). To improve validity and representativeness of the studies, larger samples could be obtained. In addition to the small number of samples, there is also a need of technical optimization of the methods themselves. Thus, the question of the most viable method cannot be answered correctly. Even though the application of fMRI enjoys great popularity, it still requires technical optimization or the addition of other methods (Logothetis, 2008). Yarkoni et al. (2010) even assume that fMRI scanners only detect a small number of actual neuronal activities. Therefore, it would be reasonable to combine the different methods, as is the case, for example, in the study by Gier et al. (2018). It is questionable, however, how it can be useful in agricultural economic research. With regard to agriculture, there are goods that either require interaction before purchase, such as tractors and work clothes, or are acquired according to other criteria, such as pesticides or animal feed. These types of goods could only be tested in a fragmentary way within the existing range of methods. An fMRI session, for example, could not be applied to investigate a possible machine acquisition, whereas such a realistic purchase situation could be simulated by fNIRS systems due to their mobility. The application in practice is therefore a question of the appropriate method. In principle, however, the visualization of these goods can be used to investigate the preferences and effects of marketing measures, as demonstrated in some of the studies presented using food and beverages (Venkatraman et al., 2012). Furthermore, fNIRS technology is used for the investigation of the neuronal effects of various food components (Jackson and Kennedy, 2013).

The number of studies on agro-economic issues using neuroscientific methods opens up a wide range of future-oriented options. Continuing technological progress will undoubtedly lead to an optimization of existing technologies and the development of new methods. Yarkoni et al. (2010), for example, argue that better automation and standardization of data acquisition and analysis should be initiated in the form of new software solutions. Besides the technology itself, there are future challenges that result from biological and evolutionary conditions and thus affect humans. Consumer interests and preferences are heterogeneous in nature, which is why the use of neuroscientific methods for market segmentation purposes seems to make sense. More date and information on the individuality of consumers can, for example, be used to target consumer groups (Venkatraman et al., 2012). Plassmann et al. (2015) proclaim three challenges that neuroeconomics will face in the future. The first of these is the fact that research provides correlates but no causal evidence, so that an understanding of the functioning of the human brain but not of behavior is generated. Secondly, conclusions from studies are often based on interpretations of earlier results, if, for example, similar brain activations were found there. The authors see the third challenge in generalization and reliability of neuroscientific research itself. In addition, the question arises, as to who can ultimately benefit from neuroeconomic research in the short or long term. When applied conscientiously, neuroeconomics can be used, for example, to initiative more conscious behavior by consumers in everyday situations as food shopping. In this way, uncertainty on the part of the consumer, for example with regard to a healthy diet, can be prevented by establishing appropriate political measures. At the same time, marketers have the opportunity to design and tailor products more specifically to consumer needs. The creation of win-win 
situation can be achieved by taking one decisive factor into account: if sufficient transparence about the intentions and purposes of the research and the measures to be established to influence behavior is created, potential uncertainty and mistrust among the actors involved can be avoided (Ariely and Berns, 2010).

Whether ethics in neuroeconomics plays a role for the consumer is a question that constantly arises. Depending on the user or addressee, different positions and views can be taken here. As mentioned earlier, neuroeconomics is made up the sub areas of consumer neuroscience as well as neuromarketing and neurofinance. The primary goal of neuromarketing is to maximize profits and identify measures to promote sales (Hubert, 2010). Especially in this research discipline, the emergence of ethical concerns from the consumer's perspective is not unreasonable. Due to the diverging interests of companies and consumers, a possible concern could be the protection human intellectual property. The discovery of decision-relevant neuronal mechanisms could, as a result, cause the consumer to become transparent, which in turn would lead to human distrust. To counteract this, Ariely and Berns (2010) suggest creating transparency about the intentions of the initiator. In this conflict, a compromise should be found between intellectual property and transparency. In principle, however, preferences are differentiated, so that the individual consumer is largely free to decide whether to reveal his or her own preferences. This is accompanied by possible concerns resulting from marketing placebo effects (McClure et al., 2004; Plassmann and Weber, 2015). Shiv et al. (2005) provide a plausible approach to this, assuming in an exemplary way that a marketer falsely promises benefits for the consumer from the purchase or use of a product and therefore increases the product price. These product advantages, which do not exist in reality, could, however, be verified for the consumer if placebo effects arise from marketingbased beliefs, which in turn legitimizes these measures. Another example stated by Ariely and Berns (2010) is the possible triggering of an ethical dilemma if food can be produced that is tailored to neural responses in such a way that consumers consume too much and tend to become obese due to the long-term energy surplus. Neuroeconomics should be predominantly applied to help people form healthy decisions about their nutrition. Consumer Neuroscience tries to uncover neuronal mechanisms that influence consumer behavior in economic situations. As mentioned earlier, the samples of neuroeconomic experiments are extremely low, with a few exceptions in eye-tracking studies. A possible danger evolves when the findings of selected studies with low sample sizes are generalized. An example of this would be when political institutions want to initiate measures for a larger population group, but these measures are not sufficiently validated in terms of their efficiency. In order to avoid confusion and mistrust on the part of consumers, there is a need to generate representative evidence and to make use of it. Furthermore, the general reaction of consumers is questionable when they learn that neuroscientific methods have been used for the marketing of certain products (Ariely and Berns, 2010).

\section{Conclusions and recommendations}

The research discipline of neuroeconomics has gradually established itself since the turn of the millennium. As this study shows, current questions related to agricultural economics could be examined from a new perspective using neuroscientific methods. The key findings show three categories in which agricultural economic research issues have been considered. These include brands and preferences, nutritional as well as purchasing behavior and advertising and marketing. Within the framework of agricultural and food marketing, neuroeconomics open up new perspectives explaining consumer purchasing behavior as well as underlying motives but also to the perception of agriculture and its practices. Recent studies assume that the knowledge gained through neuroeconomics can expand and promote social acceptance of agriculture by addressing issues such as animal husbandry or sustainability at the neural level through appropriate communication strategies, such as framing. Future research should focus on the effect of brand names or logos and the effects of product groups that suggest certain attributes to the consumer, such as superfood and 'light' products, at the neural level. Thanks to the technological maturation of mobile neuroscience methods, such as fNIRS, experiments can be carried out directly at the point of sale or on the farm, which enables a gradual approach to field conditions. These technical opportunities can prospectively be used on a larger scale when developing and implementing new products on the market. In this regard, companies like Coca-Cola actually hold a pioneering role as they already carry out neuroscientific research to check whether brand 
design, marketing and positioning in the market match the detected brain activities and attention of potential consumers with the aim to optimize their products with respect to these findings. Thus, specific managerial implications for companies from agribusiness derived from our results could be to establish, neuroeconomics methods at different stages of the development process of new products. When having an idea for a new product, companies could check with the help of fMRI/fNIRS studies, whether the product attributes cause negative (e.g. disgust) or positive (e.g. curiosity) emotions among potential consumers. Replicating these studies could help optimizing the product with regard to e.g. texture, taste, appearance or smell or compare certain product characteristics regarding consumers' preferences. The detection of brain regions associated with preferences could also help companies to learn how these preferences can be directed through different logos (e.g. fair-trade, organic, regional). Companies can use this information to optimize the labeling of their product. Furthermore, eye tracking studies could be used during the development process of new products to learn which kind of packaging attract consumers' attention and how product related information should be presented on the packaging to achieve attention. Optimizing the packaging of a product can increase consumers' willingness to pay for it. Despite this, it is also crucial for the market success of a new product to place it in the right market environment. As visual stimuli influence consumers' buying decisions, eye tracking studies could be used by companies to find the right positioning at the point of sale. Furthermore, companies could investigate the (positive) effects of their product with regard to brain activities (e.g. increase of cognitive performance) by fMRI/fNIRS studies. This information can then be used for advertising and marketing of the product.

\section{Conflict of interest}

The authors declare no conflict of interest.

\section{References}

Araujo, I.E.T., E.T. Rolls, M.L., Kringelbach, F. McGlonce and N. Phillips. 2003. Taste-olfactory convergence, and the representation of the pleasantness of flavour, in the human brain. European Journal of Neuroscience 18(7): 2059-2068. https://doi.org/10.1046/j.1460-9568.2003.02915.x

Ariely, D. and G.S. Berns. 2010. Neuromarketing. The hope and hype of neuroimaging in business. Nature Reviews. Neuroscience 11(4): 284-292. https://doi.org/10.1038/nrn2795

Attwell, D. and C. Iadecola. 2002. The neural basis of functional brain imaging signals. Trends in Neurosciences 25(12): 621-625. https://doi.org/10.1016/S0166-2236(02)02264-6

Ballco, P., T. De-Magristris and C. Vincenzina. 2019. Consumer preferences for nutritional claims: an exploration of attention and choice based on an eye-tracking choice experiment. Food Research International 116: 37-48. https://doi.org/10.1016/j.foodres.2018.12.031

Bear, M., B. Connors and M. Paradiso. 2016. Neuroscience. Exploring the brain. Wolters Kluver, Philadelphia, PA, USA.

Beaver, J.D., A.D. Lawrence, J. Van Ditzhuijzen, M.H. Davis, A. Woods and A.J Calder. 2006. Individual differences in reward drive predict neural responses to images of food. Journal of Neuroscience 26(19): 5160-5166. https://doi.org/10.1523/JNEUROSCI.0350-06.2006

Bernheim, B.D. 2009. On the potential of neuroeconomics: a critical (but hopeful) appraisal. American Economic Journal: Microeconomics 1(2): 1-41. https://doi.org/10.1257/mic.1.2.1

Busch, G., S. Gauly and A. Spiller. 2015. How do images from modern animal husbandry in agriculture affect consumers? New approaches from the field of neuromarketing. Schriftreihe der Rentenbank 31: 67-94. (in German)

Crespi, J.M., J.L. Lusk, J. Bradley, C. Cherry, L.E. Martin, B.R. McFadden and A.S. Bruce. 2015. Neural activations associated with decision-time and choice in a milk labelling experiment. American Journal of Agricultural Economics 98(1): 74-91. https://doi.org/10.1093/ajae/aav049

Del Parigi, A., K. Chen, A.D. Salbe, E.M. Reiman and P.A. Tataranni. 2005. Sensory experience of food and obesity: a positron emission tomography study of the brain regions affected by tasting a liquid meal after a prolonged fast. NeuroImage 24(2): 436-443. https://doi.org/10.1016/j.neuroimage.2004.08.035 
Duchowski, A. 2007. Eye tracking mythology. Springer, London, UK.

Ellis, S.F., M. Kecinski, K.D. Messer and J.L. Lusk. 2019. A neuroeconomic investigation of disgust in food purchasing decisions. APEC Research Reports RR19-08. Department of Applied Economics and Statistics, University of Delaware, Newark, NJ, USA.

Enax, L., Y. Hu, P. Trautner and B. Weber. 2015a. Nutrition labels influence value computation of food products in the ventromedial prefrontal cortex. Obesity 23(4): 786-792. https://doi.org/10.1002/oby.21027

Enax, L., V. Krapp, A. Piehl and B. Weber. 2015b. Effects of social sustainability signaling on neural valuation signals and taste-experience of food products. Frontiers in Behavioral Neuroscience 9: 247. https:// doi.org/10.3389/fnbeh.2015.00247

Enneking, U., R. Kleine-Kalmer, A. Dauermann and R. Voigt. 2019. Willingness to buy packaged pork products in food retail: real-life experiment and cash register zone survey. Study in cooperation with the Initiative Animal Welfare and the EDEKA regional company Minden-Hannover, pp. 1-18. (in German)

Federal Ministry of Food and Agriculture. 2016. Germany as it eats. The food report 2016. Available at: https://www.bmel.de/SharedDocs/Downloads/DE/Broschueren/Ernaehrungsreport2016.pdf? blob $=$ publicationFile \&v $=4$ (in German)

Francisco, A.J., A.S. Bruce, J.M. Crespi, J.L. Lusk, B. McFadden, J.M. Bruce, R.L. Aupperle and S.L. Lim. 2015. Are consumers as constrained as hens are confined? Brain activations and behavioral choices after informational influence. Journal of Agricultural and Food Industrial Organization 13(1): 113119. https://doi.org/10.1515/jafio-2015-0022

Gier, N., C. Krampe and P. Kenning. 2018. Perception of livestock farming - all a question of communication? Journal of Consumer Protection and Food Safety 13: 145-236. https://doi.org/10.1007/s00003-0171144-7 (in German)

Graham, D.J. and R.W. Jeffery. 2012. Predictors of nutrition label viewing during food purchase decision making: an eye tracking investigation. Public Health Nutrition 15(2): 189-197. https://doi.org/10.1017/ S1368980011001303

Groeppel-Klein, A., C.C. Germelmann, A. Domke and H. Woratschek. 2005. Arousal as a driving force for decision-making: empirical results from measuring electrodermal reactions at the point-of-sale. $N A$ - Advances in Consumer Research 32: 429-430.

Hare, T.A., J. Malmaud and A. Rangel. 2011. Focusing attention on the health aspects of foods changes value signals in vmPFC and improves dietary choice. Journal of Neuroscience 31(30): 11077-11087. https://doi.org/10.1523/JNEUROSCI.6383-10.2011

Houser, D. and K. McCabe. 2014. Experimental economics and experimental game theory. In: P.W. Glimcher and E. Fehr (eds.) Neuroeconomics. decision making and the brain. Academic Press, San Diego, CA, USA, pp. 19-34. https://doi.org/10.1016/B978-0-12-416008-8.00002-4

Hubert, M. 2010. Does neuroeconomics give new impetus to economic and consumer research? Journal of Economic Psychology 31(5): 812-817. https://doi.org/10.1016/j.joep.2010.03.009

Hubert, M., M. Huber, A. Florack, M. Linzmajer and P. Kenning. 2011. Neural correlates of impulsive buying tendencies during perception of product packaging. Psychology and Marketing 30(10): 861-873. https://doi.org/10.1002/mar.20651

Hubert, M. and P. Kenning. 2008. A current overview of consumer neuroscience. Journal of Consumer Behavior 7(4-5): 272-292. https://doi.org/10.1002/cb.251

Huettel, S.A., A.W. Song and G. McCarthy. 2009. Functional magnetic resonance imaging, $2^{\text {nd }}$ edition. W.H. Freeman, New York, NY, USA.

Jackson, P.A. and D.O. Kennedy. 2013. The application of near infrared spectroscopy in nutritional intervention studies. Frontiers in Human Neuroscience 7: 1-6. https://doi.org/10.3389/fnhum.2013.00473

Jackson, P.A., J.L. Reay, A.B. Scholey and D.O. Kennedy. 2012. DHA-rich oil modulates the cerebral hemodynamic response to cognitive tasks in healthy young adults: a near IR spectroscopy pilot study. British Journal of Nutrition 107(8): 1093-1098. https://doi.org/10.1017/S0007114511004041

Jones, G. and M. Richardson. 2007. An objective examination of consumer perception of nutrition information based on healthiness ratings and eye movements. Public Health Nutrition 10(3): 238-244. https:// doi.org/10.1017/S1368980007258513 
Karmarkar, U.R. and C. Yoon. 2016. Consumer neuroscience: advances in understanding consumer psychology. Current Opinion in Psychology 10: 160-165. https://doi.org/10.1016/j.copsyc.2016.01.010

Kennedy, D.O. and C.F. Haskell. 2011. Cerebral blood flow and behavioural effects of caffeine in habitual and non-habitual consumers of caffeine: a near infrared spectroscopy study. Biological Psychology 86(3): 298-306. https://doi.org/10.1016/j.biopsycho.2010.12.010

Kenning, P. 2014. The limits of 'rational' consumption - empirical findings and consequences for consumer policy. Journal für Verbraucherschutz und Lebensmittelsicherheit 9(3): 263-295. https://doi. org/10.1007/s00003-014-0900-1 (in German)

Khushaba, R.N., C. Wise, S. Kodagoda, J. Louviere, B.E. Kahn and C. Townsend. 2013. Consumer neuroscience: assessing the brain response to marketing stimuli using electroencephalogram (EEG) and eye tracking. Expert Systems with Applications 40(9): 2803-3812. https://doi.org/10.1016/j. eswa.2012.12.095

Kirilina, E., A. Jelzow, A. Heine, M. Niessing, H. Wabnitz, R. Brühl, B. Ittermann, A.M. Jacobs and I. Tachtsidis. 2012. The physiological origin of task-evoked systemic artefacts in functional near infrared spectroscopy. NeuroImage 61(1): 70-81. https://doi.org/10.1016/j.neuroimage.2012.02.074

Knutson, B., S. Rick, G.E. Wimmer, D. Prelec and G. Loewenstein. 2007. Neural predictors of purchases. Neuron 53(1): 147-156. https://doi.org/10.1016/j.neuron.2006.11.010

Kopton, I.M. and P. Kenning. 2014. Near-infrared spectroscopy (NIRS) as a new tool for neuroeconomic research. Frontiers in Human Neuroscience 8(549): 1-13. https://doi.org/10.3389/fnhum.2014.00549

Krajbich, I., D. Lu and A. Rangel. 2012. The attentional drift-diffusion model extends to simple purchasing decisions. Frontiers of Psychology 3(193): 1-18. https://doi.org/10.3389/fpsyg.2012.00193

Krampe, C., E. Strelow, A. Haas and P. Kenning. 2018. The application of mobile fNIRS to 'shopper neuroscience' - first insights from a merchandising communication study. European Journal of Marketing 3(1): 149. https://doi.org/10.1108/EJM-12-2016-0727

Kühn, S., E. Strelow and J. Gallinat. 2016. Multiple 'buy buttons' in the brain: forecasting chocolate sales at point-of-sale based on functional brain activation using fMRI. NeuroImage 136: 122-128. https:// doi.org/10.1016/j.neuroimage.2016.05.021

Linder, N.S., G. Uhl, K. Fliessbach, P. Trautner, C.E. Elger and B. Weber. 2010. Organic labeling influences food valuation and choice. NeuroImage 53(1): 215-220. https://doi.org/10.1016/j.neuroimage.2010.05.077

Liao, L.W., A.M. Corsi, P. Chrysochou and L. Lockshin. 2015. Emotional responses towards food packaging: a joint application of self-report and physiological measures of emotion. Food Quality and Preference 42: 48-55. https://doi.org/10.1016/j.foodqual.2015.01.009

Lloyd-Fox, S., A. Blasi and C. Elwell. 2010. Illuminating the developing brain: the past, present and future of functional near infrared spectroscopy. Neuroscience and Bio Behavioral Reviews 34(3): 269-284. https://doi.org/10.1016/j.neubiorev.2009.07.008

Logothetis, N.K. 2008. What we can do and what we cannot do with fMRI. Nature 453(7197): 869-878. https://doi.org/10.1038/nature06976

Luu, S. and T. Chau. 2009. Decoding subjective preference from single-trial near-infrared spectroscopy signals. Journal of Neural Engineering 6(1): 1.8. https://doi.org/10.1088/1741-2560/6/1/016003

McClure, S.M., J. Li, D. Tomlin, K.S. Cypert, L.M. Montague and P.R. Montague. 2004. Neural correlates of behavioral preference for culturally familiar drinks. Neuron 44(2): 379-387. https://doi.org/10.1016/j. neuron.2004.09.019

Ng, J, E. Stice, S. Yokum and C. Bohon. 2011. An fMRI study of obesity, food reward, and perceived caloric density. Does a low-fat label make food less appealing? Appetite 57(1): 65-72. https://doi. org/10.1016/j.appet.2011.03.017

O’Doherty, J.P., T.W. Buchanan, B. Seymour and R.J. Dolan. 2006. Predictive neural coding of reward preference involves dissociable responses in human ventral midbrain and ventral striatum. Neuron 49(1): 157-166. https://doi.org/10.1016/j.neuron.2005.11.014

Okada, E. and D. Delpy. 2003. Near-infrared light propagation in an adult head model. II. Effect of superficial tissue thickness on the sensitivity of the near-infrared spectroscopy signal. Applied Optics 42(16): 2915-2921. https://doi.org/10.1364/AO.42.002915 
Plassmann, H., J. O’Doherty and A. Rangel. 2007. Orbitofrontal cortex encodes willingness to pay in everyday economic transactions. Journal of Neuroscience 27(32): 9984-9988. https://doi.org/10.1523/ JNEUROSCI.2131-07.200

Plassmann, H., J. O’Doherty, B. Shiv and A. Rangel. 2008. Marketing actions can modulate neural representations of experienced pleasantness. Proceedings of the National Academy of Sciences of the United States of America 105(3): 1050-1054. https://doi.org/10.1073/pnas.0706929105

Plassmann, H., T.Z. Ramsøy and M. Milosavljevic. 2012. Branding the brain. a critical review and outlook. Journal of Consumer Psychology 22(1): 18-36. https://doi.org/10.1016/j.jcps.2011.11.010

Plassmann, H., V. Venkatraman, S. Huettel and C. Yoon. 2015. Consumer neuroscience. Applications, challenges and possible solutions. Journal of Marketing Research 52(4): 427-435. https://doi. org/10.1509/jmr.14.0048

Plassmann, H. and B. Weber. 2015. Individual differences in marketing placebo effects. Evidence from brain imaging and behavioral experiments. Journal of Marketing Research 52(4): 493-510. https:// doi.org/10.1509/jmr.13.0613

Rampl, L.V., H. Plassmann and P. Kenning. 2011. What practitioners should pay attention to. Absatzwirtschaft 5: 32-35. (in German)

Reimann, M. and B. Weber. 2011. Neuroeconomics - a review of the situation. In: M. Reimann and B. Weber (eds.) Neuroeconomics. basics - methods - applications. Springer, Wiesbaden, Germany, pp. 3-9. (in German)

Ruff, C.C. and S.A. Huettel. 2014. Experimental methods in cognitive neuroscience. Academic Press, San Diego, CA, USA.

Schilke, O. and M. Reimann. 2007. Neuroeconomics: basic understanding, methods and fields of application. Journal für Betriebswirtschaft 57(3): 247-262. https://doi.org/10.1007/s11301-007-0026-y (in German)

Schröter, I. and M. Mergenthaler. 2019. Neuroeconomics meets aquaponics: an eye-tracking pilot study on perception of information about aquaponics. Sustainability 11(13): 3580. https://doi.org/10.3390/ su11133580

Schulze, B., A. Spiller and D. Lemke. 2008. Lucky pig or poor sow: consumers' attitude to modern livestock farming. In: B. Schulze, A. Spiller and D. Lemke (eds.) Future prospects for the meat industry. Göttingen University Press, Göttingen, Germany, pp. 465-489. (in German)

Shiv, B., Z. Carmon and D. Ariely. 2005. Placebo effects of marketing actions: consumers may get what they pay for. Journal of Marketing Research 42(4): 383-393. https://doi.org/10.1509/jmkr.2005.42.4.383

Stoeckel, L.E., R.E. Weller, D.B. Twieg, R.C. Knowlton and J.E. Cox. 2008. Widespread reward-system activation in obese women in response to pictures of high-calorie foods. NeuroImage 41(2): 636-647. https://doi.org/10.1016/j.neuroimage.2008.02.031

Stoll, M., S. Baecke and P. Kenning. 2008. What they see is what they get? An fMRI-study on neural correlates of attractive packaging. Journal of Consumer Behavior 7(4): 342-359. https://doi.org/10.1002/cb.256

Vanhonacker, F., E. Van Poucke, F. Tuyttens and W. Verbeke. 2010. Citizens' views on farm animal welfare and related information provision: exploratory insights from flanders, Belgium. Journal of Agricultural and Environmental Ethics 23(6): 551-569. https://doi.org/10.1007/s10806-010-9235-9

Velaquez, C.E. and K.E. Pasch. 2014. Attention to food and beverage advertisements as measured by eyetracking technology and the food preferences and choices of youth. Journal of the Academy of Nutrition and Dietetics 114(4): 578-582. https://doi.org/10.1016/j.jand.2013.09.030

Venkatraman, V., J.A. Clithero, G. Fitzsimons, S. Huettel. 2012. New scanner data for brand marketers. How neuroscience can help better understand differences in brand preferences. Journal of Consumer Psychology 22(1): 143-153. https://doi.org/10.1016/j.jcps.2011.11.008

Ward, J. 2015. The student's guide to cognitive neuroscience. Taylor and Francis, Hoboken, NJ, USA.

Weber, B. 2016. Consumer neuroscience and neuromarketing. In: M. Reuter and C. Montag (eds.) Neuroeconomics (studies in neuroscience, psychology and behavioral economics). Springer, Berlin, Germany, pp. 333-341.

Weber, B. 2017. Neuroeconomics. In: P. Kenning, A. Oehler, L.A. Reisch and C. Grugel (eds.) Consumer science. framework conditions, fields of research and institutions. Springer, Wiesbaden, Germany, pp. 329-340. (in German) 
Weinrich, R., S. Kühl, A. Zühlsdorf and A. Spiller. 2014. Consumer attitudes in Germany towards different dairy housing systems and their implications for the marketing of pasture raised milk. International Food and Agribusiness Review 17(4): 205-222. https://doi.org/10.22004/ag.econ.188715

Yarkoni, T. 2009. Big correlations in little studies. Inflated fMRI correlations reflect low statistical powercommentary on Vul et al. (2009). Perspectives on Psychological Science: a Journal of the Association for Psychological Science 4(3): 294-298. https://doi.org/10.1111/j.1745-6924.2009.01127.x

Yarkoni, T., R.A. Poldrack, D.C. Van Essen and T.D. Wager. 2010. Cognitive neuroscience 2.0. Building a cumulative science of human brain function. Trends in Cognitive Sciences 14(11): 489-496. https:// doi.org/10.1016/j.tics.2010.08.004 